Henryk Dzwigol,

D.Sc., Professor, Silesian University of Technology, Poland

ORCID ID, 0000-0002-2005-0078

email: henryk.dzwigol@poczta.fm

Correspondence author: henryk.dzwigol@poczta.fm

\title{
META-ANALYSIS IN MANAGEMENT AND QUALITY SCIENCES
}

Abstract. This study on the methodology of conducting the research process indicates the scarcity of an empirical approach to a problem of quality of the research process. In this paper, the determinants of the quality of the research process in the management sciences were examined. The authors employed the commonly used principal component analysis (PCA), also known as factor analysis. Furthermore, the article presents a holistic, structured and configurable framework that would result in the construction of an appropriate research methodology. The research work carried out within the discipline of management sciences must be embedded both in terms of theory and practice. Although the management sciences are most often treated as applied or practical sciences, they also undertake theoretical research in their scope, because no science can develop without theoretical research. This paper aims to identify the factors influencing the quality of the research process as the complementary elements to the contemporary methodological approaches. The analysis of the domestic and foreign scientific background, as well as the drawn conclusions, turned on the modifications introduced over the years in the management methods. The management methodology is constantly expanding by new methods, the latter being of diverse cognitive and practical effectiveness. The constant growth of diagnostic instruments has been dependent, mainly, on changes occurring in the environment. Moreover, it is connected to the need to make use of more sophisticated and effective tools. The article focused on meta-analysis as a research process and qualitative approach to the research process on the example of research results. Empirical research confirms the existence of factors that constitute a criterion supporting the assessment of the quality of the conducted research process. In the management sciences, the quality of the research process is defined as verifying the degree of implementation and consistency of the objectives of the work following the research problem and conclusions.

Keywords: meta-analysis, management, research, determinants, quality, empirical approach.

Introduction. In today's science as well as economy (of the $21^{\text {st }}$ century), we have witnessed the development of management sciences shifting towards the use of non-complex and complementary methods in order to consider all aspects of the same problem (Coghlan and Shani, 2016; Harrington and Voehl, 2016; Arefieva et al., 2021; Bogachov et al., 2020; Cyfert et al., 2020; Czakon et al., 2020; Dementyev and Kwilinski, 2020; Dyduch, 2019a, 2019b; Dzwigol et al., 2020; Gorynia, 2019; Gorynia et al., 2019; Kwilinski, 2018a, 2018b; Kwilinski et al., 2019, 2020a, 2020b, 2020c; Kwilinski and Kuzior, 2020; Kyrylov et al., 2020; Melnychenko, 2019, 2020; Miskiewicz, 2019, 2020a; Miskiewicz and Wolniak, 2020; Tkachenko et al., 2019a, 2019b). The literature on management sciences has repeatedly emphasised the need to simultaneously apply several mutually verifying and correcting methods (Denzin, 1970; Harrington and Voehl, 2016). Moreover, the phenomenon of methodological pluralism has emerged, implying that to solve a research problem, one is ready to apply research methods drawn from various disciplines and theoretical approaches. This means that «the multitude of ways of seeing the world is accompanied by a multitude and diversity of ways, methods, techniques of research, and attempts to transform the world». However, this leads very often to anarchism as well as methodological eclecticism. Therefore, to obtain reliable research results, it is necessary to carefully analyse the explored problem and select such research methods that would make it possible to avoid the above-mentioned phenomena.

The requirement for researchers is both to summarise the results of foreign research and to

Cite as: Dzwigol, H. (2021). Meta-Analysis in Management and Quality Sciences. Marketing and Management of Innovations, 1, 324-335. http://doi.org/10.21272/mmi.2021.1-25 
incorporate them into the development of their own research concepts and projects (Gurevitch et al., 2018). Among several methods for critical literature review, the methodology of meta-analysis is becoming increasingly important, especially in the era of digitalisation. It is present in the technical and social sciences, however, it is slowly permeating other fields as well, including the management sciences (Hung, 2019). According to Field, the meta-analysis methodology is particularly recommended for social and behavioural research (Field, 2001) - yet, for years there has been growing interest in this method among researchers in other sciences, including management and economics (Fikrat-Wevers et al., 2021; Vazquez et al., 2018; Boiko et al., 2019; Dalevska et al., 2019; Kharazishvili et al., 2020; Lyulyov et al., 2021; Melnychenko, 2021; Miskiewicz, 2020b). G. V. Glass defined meta-analysis as statistical analysis of a set of results that are derived from different studies and serve to integrate previous findings (combining results is done according to a specific statistical procedure) (Glass, 1976). Methodology using statistical methods allows combining the results of different studies (Glass, 1976) to come up with own conclusions for these studies. At the same time, meta-analysis provides a way to assess the validity of research findings and to synthesise them. Moreover, it makes it possible to identify relationships not identified in primary research, or test the effects of different moderators, and discover trends that may have gone unnoticed using other research approaches (Aguinis et al., 2011; Cooper, 2010; Hunter and Schmidt, 2015). In the management sciences, meta-analysis can also provide a basis for the formulation of research hypotheses, as well as for the explanation of the phenomena and processes under study and the search for a new research area (Gondek and Mazur, 2014).

The present paper focuses on presenting the factors that determine the quality of the research process in management and quality sciences. More specifically, it seeks to answer the research question: What factors determine the quality of the research process in the management sciences.

Literature Review. Meta-analysis is part of an evidence-oriented research approach. It entails combining the results of previous work, the practical experience of companies and the preferences and values of consumers (Sagan, 2009), while in meta-analysis it is important to identify the common denominator of the results of numerous studies and to present a summarised statistical conclusion for them (Sauerbrei and Blettner, 2003). The growing popularity of meta-analysis is due to researchers' demand for reliable information about the effectiveness of different tools used by companies. Researchers from different parts of the world attempt to address similar issues. However, their work is often pursued in different ways (Lipsey and Wilson, 2001). Besides, there is a very strong demand in science for original research papers that are exploratory, bringing opportunities to solve research problems. On the other hand, however, the need to undertake replication of completed studies is also considerable. The popularisation of the meta-analysis was determined by its following features (Sacks et al., 1987):

- integrating and interpreting aggregated results from diverse studies;

- basing the analysis on the entire set of literature dealing with a given problem, instead of relying on single reports;

- the precise estimation of similarities and differences in the methodology of individual papers;

- statistical, rather than subjective, assessment of the effect size;

- reliable development of conclusions based on integrated results, which significantly increases the research value.

The meta-analysis as a research process consists of four stages (Dincer, 2018):

Stage I: conceptualisation and operationalisation of the research problem based on a preliminary analysis of available research results (Saunders et al., 2018) - it focuses on the emergence of a research problem arising from the researcher's research-related experience and a preliminary review of the results of any previous research. The selection of appropriate methods for obtaining information about the research conducted so far becomes crucial at this stage. Valuable research results should be published 
by the researcher in reputable journals, which can be found in full-text databases of electronic journals e.g. EBSCO, ProQuest, ELSEVIER, Wiley-Blackwell, JSTOR, Emerald.

Stage II: data collection with the use of inclusion criteria - the selection of appropriate criteria depends, in particular, on the individual needs of the researcher. The criteria may concern, among others: the period of analysis, the applied research method, the territorial range of the study, the quality of the study, the size of the study population, the quality of publications. It should be borne in mind that the criteria for including studies in the meta-analysis may significantly affect its quality.

Stage III: selection and compilation of study results - conducted studies should be analysed to obtain a compilation containing elements as follows: study code, source, correlation coefficient or other study size and comparisons, study sample size, p-value. The summary may also include elements for preliminary statistical analysis: total size of the study population, weighted average of correlation coefficients (weights will be shares of particular study populations in the total population), minimum correlation coefficient, maximum correlation coefficient.

Stage IV: statistical analysis and formulation of conclusions (statistical inference procedure) - main analytical objectives of this stage are to combine the results of the available studies, to analyse the distribution of the effect size and to examine the relationship between the effect size(s) and other descriptive variables. This will reveal the variability in effect size across studies included in the metaanalysis. For reasons of comprehensiveness, this step will be described below.

In the meta-analysis, a tool called meta-regression is used to examine the influence of variables on the effect value, with the use of regression (Gondek and Mazur, 2014). This tool, from the point of view of management science, is of great use, as it allows not only to identify the variables influencing the value of the effect but also to determine the strength of this influence (this advantage is particularly important when constructing structural models) (Gondek and Mazur, 2014). Various meta-regression methodologies can be found in the literature. Meta-regression can be applied to both a set of studies included in a metaanalysis (Doucouliagos and Laroche, 2003) and groups of studies (Thompson and Sharp, 1999). Groups of studies included in the meta-analysis can be evaluated to determine the association of specific variables with the explanatory variable (Gondek and Mazur, 2014).

In the field of management sciences, meta-analysis can perform various functions. The main purposes can be put as follows (Gondek and Mazur, 2014):

- testing research hypotheses (Meyer et al., 2017) - increasing the research sample improves the quality of the test;

- the basis for formulating research hypotheses;

- searching for new research areas that may emerge by compiling results from worldwide studies;

- hint to abandon a line of research when low correlation coefficients are obtained in repeated studies;

- developing research problems;

- explaining researched phenomena and processes by taking into account various aspects of research and their tabulation.

The meta-analysis can assume many forms: horizontal (area study) - it is admissible to accept even single results in case they may fill in specific areas of the studied reality, and vertical (effect size study) (Gondek and Mazur, 2014). The meta-analysis, like any other method, has its advantages and disadvantages. The advantages can include: taking into account sample and effect sizes, using the final results of the study, or taking into account the combination of different study results, etc. On the other hand, disadvantages may include the lack of possible comprehensive syntheses, the limitation to include the quantitative part of the studies, the limitations on the minimum number of studies, etc. Notwithstanding the limitations, the method is a valuable research tool and can support many scientific processes, especially using the principles of triangulation. 
In conclusion, the meta-analysis is less opinionated and subjective than other literature review methods. It takes into account both the data and the sample size (King and $\mathrm{He}, 2006)$. Furthermore, it can be both a main research method and a supporting research process that is based on the author's research design (Gondek and Mazur, 2014). The advantages of meta-analysis can be examined in two areas:

1. Understanding the meta-analysis as a method that is used to assess the validity of scientific findings.

2. Understanding the meta-analysis as a methodologically rigorous method that allows synthesising scientific results.

Research methods and techniques in management science are primarily aimed at learning about the rules and principles that govern organisations and improving them (Quinlan et al., 2019). A method can be defined as a deliberate and consistent way of proceeding or acting by the researcher that determines the achievement of the intended goal (Dzwigol et al., 2019a). A technique, on the other hand, can be defined as a tool that is used to solve emerging problems (Dzwigol et al., 2019b). In practice, distinguishing between a method and technique is not a simple matter. However, regardless of whether a research method or technique is used, the researcher must always apply a specific research process (Bryman, 2006; Vaivio et al., 2010). This process consists of many elements that should be carefully planned based on continuous choices made for the sake of reliability and validity of the research results (Cooke, 2003). When analysing the literature on phenomena and problems of interest to the researcher and their solutions, the researcher must also be guided by the principle of intersubjective verifiability. According to this principle, the results of other people's research should be verified and checked (Grudzewski and Hejduk, 2007). It is necessary to state that despite critical remarks, the management science, as well as its methodology and methods lead to the increase of effectiveness, as well as the competitiveness of enterprises. However, it is worth noting that management methods are not and cannot be universal. The methods in question have to change over time, just as the enterprise changes over time. Most scientific disciplines have separate, proper and diverse cognitive methods, allowing to solve or diagnose a research problem, while the methodology of management does not necessarily have a permanent, universal character. Methods specific to other sciences, including psychology, social sciences, statistics, econometrics or economics, are used in management. Management methodology is a reflection on the transformations that have taken place over the years in management methods that provide an insight into the state in which a company operates. It is constantly being extended by new methods characterised by varying cognitive and practical effectiveness. The continuous development of diagnostic instruments is conditioned primarily by changes in the environment. In the literature on management science, the necessity of simultaneous use of a wide variety of methods of cognition and shaping of the organization has been repeatedly emphasised (Labarca, 2017; Patton, 2002).

Methodology and research methods. Conclusions resulting from the analysis of the literature on the methodology of conducting research processes indicate the scarcity of an empirical approach to the problem which is the quality of the research process. Thus, the research problem was framed as follows: What factors determine the quality of the research process in the management sciences?

For this reason, the research undertaken in the present paper is aimed at distinguishing factors influencing the quality of the research process as a complementary element to previous methodological approaches. As a result of the stated objective, the research was conducted using an anonymous survey questionnaire distributed in paper form at conferences on management-related issues and electronically as a result of a previously compiled email database. The research was conducted between October 2016 and April 2018.

The structure of the survey questionnaire consisted of three parts, where the first one included questions on the relevance of approaches, processes, methods and techniques in the research process in management science (5 questions). The second comprised questions on the raised problem of 
improving the research process (33 questions). The third part included demographics (3 questions). The design of the questionnaire in the research part was based on both open-ended, rank questions and based on a five-point Likert scale. The respondents were required to indicate a specific scale of application: strongly agree (5), agree (4), neither agree nor disagree (3), disagree (2), strongly disagree (1), to each of the proposed issues (Dzwigol and Wolniak, 2018).

Characteristics of the research group. The research was addressed to the theorists of management sciences as a target group consisting of academics related to the field of management sciences and enterprises. The study sample presented by 272 foreign universities with departments and/or units related to the management science; 21,024 foreign academics affiliated with the management sciences discipline; 93 domestic universities with departments and/or units related to the discipline of management sciences; 2,307 domestic academics affiliated with the management sciences discipline; 52 foreign companies; 183 domestic companies).

Data analysis. For assessing factors determining the quality of research processes in management sciences, one applied a commonly used method of principal component analysis (PCA), also known as factor analysis (Trajer et al., 2012).

The main aim of conducting the factor analysis was to identify all factors being directly correlated to a given set of variables, while maintaining, at the same time, the greatest amount of information contained in initial variables, which was then followed by their reduction. A statistical analysis of results was conducted using a statistical programme named Statistica 13. The software in question has been in widespread use for the analysis of statistical data (Fojud et al., 2017).

Results. The analysis of research results included their preparation using descriptive statistics tools. It should be emphasised that the obtained results are preliminary. Besides, they are the basis for further in-depth research, which is the subject of other studies. In compliance with method-related assumptions, referring to the fulfilment of basic requirements for carrying out the factor analysis, one should take the following steps, destined to prove that the method in question was correctly selected:

- verification of several variables against some respondents taking part in the study;

- $\quad$ the Bartlett test (of sphericity);

- $\quad$ the KMO and MSA measures.

In the beginning, the condition referring to the number of observations and variables was studied. In the case in question, 33 variables and 401 surveyed respondents were analysed, which means that the condition was met. To conduct the Bartlett test, the following zero hypotheses $(\mathrm{H} 0)$ and alternative hypothesis ( $\mathrm{H} 1)$ were applied:

$\mathrm{H}_{0}$ - the matrix containing variable correlations is a unit matrix.

$\mathrm{H}_{1}$ - the matrix containing variable correlations is not a unit matrix.

Table 1. The Bartlett test of sphericity (results are relevant when $p<0.05$ )

\begin{tabular}{cccc}
\hline Empirical Chi ${ }^{2}$ & Levels of freedom & p-value & Theoretical Chi $^{2}$ \\
\hline $\mathbf{4 8 3 0 . 7 9}$ & 528 & $<0.001$ & 582.56 \\
\hline
\end{tabular}

Sources: developed by the authors.

Since the empirical chi2 exceeds the theoretical chi2, $\mathrm{H}_{0}$ is rejected in favour of $\mathrm{H}_{1}$. Therefore, it transpires that variables are suitable for the factor analysis. The KMO Measure (Kaiser-Meyer-Olkin Measure of Sampling Adequacy), in the covered study, amounts to 0.835. Analysing the results obtained, the MSA (Measure of Sampling Adequacy) was additionally checked. After the analysis, it can be concluded that each of the questions meets the MSA measurement threshold mentioned above. 
Table 2. Results of the MSA analysis

\begin{tabular}{|c|c|c|}
\hline Question & $\begin{array}{l}\text { Variable } \\
\text { number }\end{array}$ & $\begin{array}{l}\text { MSA } \\
\text { reference }\end{array}$ \\
\hline Is the Management science discipline destined to support practical aspects of economic life? & P1 & 0.850 \\
\hline Should a researcher provide models of effective organisation- and management-related solutions? & $\mathrm{P} 2$ & 0.805 \\
\hline Should a researcher provide methods to implement models of effective solutions? & P3 & 0.818 \\
\hline $\begin{array}{l}\text { Is it necessary that the research studies, carried out within the scope of the Management science } \\
\text { discipline, be practically and theoretically set? }\end{array}$ & P4 & 0,869 \\
\hline Is the instability of statements the main drawback connected with Management science? & P5 & 0.852 \\
\hline $\begin{array}{l}\text { Does the research cover, in most cases, those variables which depend on various conditions: } \\
\text { operating conditions, weather and environmental conditions, legal or social conditions, etc? }\end{array}$ & P6 & 0.883 \\
\hline $\begin{array}{l}\text { Does the complexity of research objects (e.g. companies) have a negative impact on the credibility of } \\
\text { research findings? }\end{array}$ & P7 & 0,846 \\
\hline $\begin{array}{l}\text { Does the application of qualitative factors, difficult to measure, affect the quality of a research } \\
\text { process? }\end{array}$ & P8 & 0.817 \\
\hline $\begin{array}{l}\text { Are the advocated and applied methods assessed differently by management theorists and } \\
\text { practitioners? }\end{array}$ & P9 & 0.790 \\
\hline $\begin{array}{l}\text { Are there any problems in terms of verifiability of findings of research studies, carried out in the } \\
\text { Management science discipline? }\end{array}$ & P10 & 0.786 \\
\hline $\begin{array}{l}\text { Should the cooperation between science and business practice be strategic in the process of } \\
\text { managing a modern company? }\end{array}$ & P11 & 0.873 \\
\hline $\begin{array}{l}\text { In the Management sciences, does the time between posing a problem, analysing and finding a } \\
\text { solution to the problem, and implementing the said solution negatively influence the effectiveness of } \\
\text { the solution? }\end{array}$ & P12 & 0.909 \\
\hline Is there universalism of elaborated concepts, solutions to problems in the Management sciences? & $\mathrm{P} 13$ & 0.794 \\
\hline Is methodological triangulation a prerequisite in research processes? & P14 & 0.802 \\
\hline Should qualitative methods in research processes be completed with case studies? & P15 & 0.865 \\
\hline $\begin{array}{l}\text { Is it necessary, to make the research reliable, to verify the elaborated methods, procedures and } \\
\text { models in practice? }\end{array}$ & P16 & 0.860 \\
\hline Can pilot studies affect the direction of a research process? & P17 & 0.875 \\
\hline Is it necessary to create a model, procedure, tool or approach for the sake of a research process? & P18 & 0.885 \\
\hline $\begin{array}{l}\text { Is it possible for a researcher to match chosen methods to the character of the research study in } \\
\text { question? }\end{array}$ & P19 & 0.701 \\
\hline $\begin{array}{l}\text { Does a researcher have an impact on combining qualitative and quantitative methods in a research } \\
\text { process? }\end{array}$ & $\mathrm{P} 20$ & 0.720 \\
\hline Do pilot studies affect the course of a research process? & P21 & 0.862 \\
\hline $\begin{array}{l}\text { Does the elaboration of models, procedures, tools or approaches in the research process guarantee } \\
\text { the credibility of results? }\end{array}$ & $\mathrm{P} 22$ & 0.884 \\
\hline Is it necessary to elaborate assumptions to create research methods? & $\mathrm{P} 23$ & 0.884 \\
\hline $\begin{array}{l}\text { Do the recommendation for management science and practice, elaborated based on research results, } \\
\text { improve the quality of science and practice? }\end{array}$ & P24 & 0.845 \\
\hline $\begin{array}{l}\text { Does the elaborated model, procedure, tool or approach to the methods selected for a research } \\
\text { process considerably affect the quality and application of research results? }\end{array}$ & $\mathrm{P} 25$ & 0.823 \\
\hline $\begin{array}{l}\text { Is it necessary, upon determining the research problem, to analyse selected qualitative and } \\
\text { quantitative methods, to make a preliminary selection? }\end{array}$ & $\mathrm{P} 26$ & 0.840 \\
\hline Are pilot studies an integral component of each research process? & $\mathrm{P} 27$ & 0.801 \\
\hline $\begin{array}{l}\text { Is the verification of elaborated methods, models or procedures a prerequisite to combine } \\
\text { management science and practice? }\end{array}$ & $\mathrm{P} 28$ & 0.856 \\
\hline Does the methodological triangulation support research processes? & $\mathrm{P} 29$ & 0.843 \\
\hline Does a case study allow to perform an in-depth analysis of a research process? & P30 & 0.813 \\
\hline $\begin{array}{l}\text { Should the expert group assessment be regarded as a basic method of evaluating trends of the } \\
\text { carried-out research? }\end{array}$ & P31 & 0.849 \\
\hline $\begin{array}{l}\text { Is it important to carry out observations of research studies in natural conditions, in which a } \\
\text { researcher co-operates with researched subjects? }\end{array}$ & P32 & 0.794 \\
\hline $\begin{array}{l}\text { What is the importance of observation-interventions conducted with the scope of managerial activity } \\
\text { in the researched subjects, whereas a researcher can directly influence the decisions taken? }\end{array}$ & P33 & 0.766 \\
\hline
\end{tabular}

Sources: developed by the authors. 
In this particular case, the research process is the central variable. Based on the presented results, 8 factors have been identified that meet the mentioned Kaiser criterion and it has been concluded that this number is sufficient to illustrate the problem.

In the analysed case, the factor rotation was performed with the use of the EQUAMAX method which allows distributing, in a uniform way, a variance between factors. The method also reduces the number of factors required for the sake of explaining variances. The threshold loading was set to 0.5 . In the case in question, under 8 defined factors, one can explain $59.32 \%$ of the research process.

1. Application and purposefulness in practice (P1-P4) - the factor understood as an opportunity to fulfil a scientific target, i.e. opportunity to implement the research process in question into the operation of companies and real economic life.

2. Impact of diversity of problems onto the process (P5-P8; P11; P30) - the factor understood as an answer to the question of how the selected research problem will determine further research actions?

3. Influence of a researcher (P19-P21) - the factor that associates with the scope of free decisions taken by the researcher while dealing with a problem.

4. The unique character of a scientific discipline (P9-P10) - the factor shows differences in how practitioners and theoreticians evaluate the selected methods, which makes it difficult to assess, in an objective way, the verifiability of the conducted research studies.

5. Importance of observations (P32-P33) - the factor shows the impact of two types of observation. The first type of observation deals with the opportunity to co-operate with other entities, the second types involves the so-called observation followed by a possible intervention.

6. Completeness of the process (P24-P26) - the factor is understood as an opportunity to divide the research process into stages that form a complementary whole, i.e.: combining qualitative and quantitative methods, elaborating a unique tool, model, approach to the way a method or procedure is selected, indicating recommendations as to scientific and practical aspects.

7. A type of a supported process (P15; P17; P21) - the factor is understood as an impact on the course and management of the research process using pilot studies and case studies.

8. The need for triangulation and universalism of the conducted research (P13; P14) - the factor shows, to a certain extent, a forced requirement for the management sciences to develop. However, a failure in meeting the requirements does not necessarily mean a failure in finding an original solution to the research problem.

Conclusions. The essence of the research process is the formulation of the research problem, by which the research objectives are established. The formulation of the research problem is the starting point for developing the research concept (Schwartz-Shea and Yanow, 2013). According to the holistic approach, phenomena create holistic systems (Chen et al., 2018). Viewing organisations holistically is a feature of systems thinking (Williams et al., 2017). It is thus necessary to make use of the systems methodology, which requires to design actions collaboratively (in the holistic sense (Holmes et al., 2012). The ensuing results will be to establish proper research methodics. Moreover, in contemporary management sciences, the postulates of methodological eclecticism (Barker et. al., 2001) play an important role; within this framework, research methods are divided into inductive and deductive methods. What is more, in management, there are no unequivocal or definitive conclusions and firm conclusions that can be interpreted as indelible universal laws. This is because each phenomenon or problem analysed is unique, and may have several solutions, additionally rapidly becoming obsolete (Rahi, 2017; Merigo and Yang, 2017). Therefore, it is considered that knowledge in the field of management sciences is as follows: non-universal, non-approximate, uncertain. When analysing the literature on phenomena and problems of interest to the researcher and their solutions, the researcher, moreover, must be guided by the principle of intersubjective verifiability. According to this principle, the results of others' research should be verified and checked (Boland et al., 2017). As science itself and related research work are increasingly 
more closely linked to business practice than they used to be (Ludeke-Freund and Dembek, 2017; DarlingHammond et al., 2020), the research work carried out within the discipline of the management sciences must be embedded in both theoretical and practical perspectives. Although management sciences are most often treated as applied or practical sciences, it is important to bear in mind that they also undertake theoretical research in their scope, as no science can develop without theoretical research (Mohajan, 2018). It is also worth noting that the relationship between management science and business practice is two-sided and additionally complex. However, it is worth referring to meta-analyses of management science, critically approaching its output over the last few decades. Management fashion theory (Madsen and Slatten, 2019; Oesterreich et al., 2020) considers the output of management science precisely from the meta-level, i.e. it is interested in analysing the processes of creation and dissemination of management approaches, models and tools. Increasingly, attention is paid to the application of a package of diverse methods (Dzwigol et al., 2019) to achieve consistency based on empirical inference (Kostera, 2003). However, it should be pointed out that convergent results do not imply consistent or identical research results because the results obtained may not be identical. In turn, they allow a deeper understanding of the relationship between the researcher's approach and the analysed phenomenon. Numerous authors ignore ontological and epistemological issues and their links to the methodology by overly focusing on empirical problems. It is possible to combine methods, but under obligation to hold on to the same theoretical position (ontological and epistemological) (Heesen et al., 2019). The author cannot be a positivist while using quantitative methods and a relativist while using qualitative methods. Different researchers would interpret their results in different ways: a positivist considers the results obtained to be «true», while a relativist could conclude that they have discovered one possible interpretation (Heesen et al., 2019; Joslin and Muller, 2016).

Every empirical study has its limitations. Therefore, combining the research results from the different methods used allows for their partial neutralisation. This action consists of correcting certain distortions that have arisen as a result of measurement errors, sampling errors, research context (Pyrczak, 2016) or research design. The possibility of combining research results is provided by the use of the meta-analysis method (Gurevitch et al., 2018). This method, as a collective quantitative analysis, makes it possible to merge the results of several studies relating to the same research problem. Meta-analysis aims to present a summary statistical result.

Identification of factors influencing the quality of the research process, being a complementary element to the contemporary methodological approaches, was the aim of this article. The analysis of the used domestic and foreign literature, as well as the drawn conclusions, make us think about the modifications introduced over the years in the management methods. The management methodology is constantly expanding by new methods, the latter being of diverse cognitive and practical effectiveness. A constant growth of diagnostic instruments has been dependent, mainly, on changes occurring in the environment; moreover, it is connected to the need to make use of more sophisticated and effective tools. In the course of the factor analysis, eight factors were identified. The factors, determining the quality of research processes, are as follows: practical application and purposefulness; influence of diverse research problems on the process; influence of a researcher on the research process; unique character of a scientific discipline; importance of observations; completeness of the process; process assistance type; need for triangulation and universalism.

The above factors constitute a criterion that supports the assessment of the quality of the conducted research process. In the management sciences, the quality of the research process was defined as verifying the degree of implementation and consistency of the objectives of the study following the research problem and conclusions set in it. The essence of the research process was to find a solution, and not the tool itself, which allowed finding this solution. 


\section{H., Dzwigol. Meta-Analysis in Management and Quality Sciences}

\section{References}

Aguinis, H., Dalton, D. R., Bosco, F. A., Pierce, C. A., \& Dalton, C. M. (2011). Meta-analytic choices and judgment calls: Implications for theory building and testing, obtained effect sizes, and scholarly impact. Journal of Management, 37(1), 5-38. [Google Scholar] [CrossRef]

Arefieva, O., Polous, O., Arefiev, S., Tytykalo, V., \& Kwilinski, A. (2021). Managing sustainable development by human capital reproduction in the system of company's organizational behaviour. IOP Conference Series: Earth and Environmental Science, 628. [Google Scholar]

Barker, A., Spackman, N., \& Nancarrow, C. (2001). Informed eclecticism: a research paradigm for the 21st century. International journal of market research, 43(1), 1-21. [Google Scholar] [CrossRef]

Bogachov, S., Kwilinski, A., Miethlich, B., Bartosova, V., \& Gurnak, A. (2020). Artificial intelligence components and fuzzy regulators in entrepreneurship development. Entrepreneurship and Sustainability Issues, 8(2), 487. [Google Scholar] [CrossRef]

Boiko, V., Kwilinski, A., Misiuk, M., \& Boiko, L. (2019). Competitive Advantages of Wholesale Markets of Agricultural Products as a Type of Entrepreneurial Activity: The Experience of Ukraine and Poland. Economic Annals-XXI, 175(1-2), 68-72. [Google Scholar] [CrossRef]

Boland, A., Cherry, G., \& Dickson, R. (Eds.). (2017). Doing a Systematic Review: A Student's Guide. London, UK: Sage. [Google Scholar]

Bryman, A. (2006). Integrating quantitative and qualitative research: how is it done?. Qualitative research, 6(1), 97-113. [Google Scholar] [CrossRef]

Chen, J., Yin, X., \& Mei, L. (2018). Holistic innovation: an emerging innovation paradigm. International Journal of Innovation Studies, 2(1), 1-13. [Google Scholar] [CrossRef]

Coghlan, D., \& Shani, A .B. (2016). Action Research in Business and Management (Fundamentals of Applied Research). London, UK: Sage. [Google Scholar]

Cooke, R.B. (2003). Probabilistic risk analysis: foundations and methods. Cambridge, UK: Cambridge University Press. [Google Scholar

Cooper, H. (2010). Research Synthesis and Meta-analysis: A Step-by-step Approach. London, UK: Sage. [Google Scholar]

Cyfert, S., Glabiszewski, W., Krzakiewicz, K., \& Zastempowski, M. (2020). The Importance of Dynamic Capabilities in the Processes of Alignment of Chemical Industry Enterprises to Changes in the Environment. Przemys/ Chemiczny, 99(6), 953-956.

Czakon, W., Kawa, A., \& Scott, S. (2020). Network orientation of logistics service providers: the construct, dimensionality and measurement scale. International Journal of Logistics Research and Applications, 23(5), 474-492. [Google Scholar] [CrossRef]

Dalevska, N., Khobta, V., Kwilinski, A., \& Kravchenko, S. (2019). A model for estimating social and economic indicators of sustainable development. Entrepreneurship and Sustainability Issues, 6(4), 1839. [Google Scholar] [CrossRef]

Darling-Hammond, L., Flook, L., Cook-Harvey, C., Barron, B., \& Osher, D. (2020). Implications for educational practice of the science of learning and development. Applied Developmental Science, 24(2), 97-140. [Google Scholar] [CrossRef]

Dementyev, V. V., \& Kwilinski, A. (2020). Institutional component of production costs. Journal of Institutional Studies, 12(1), 100-116. [Google Scholar] [CrossRef]

Denzin, N. (1970). The Research Act: Theorethical Introduction to Sociological Methods. Chicago, US: Aldine. [Google Scholar] Dincer, S. (2018). Content Analysis in Scientific Research: Meta-Analysis, Meta-Synthesis, and Descriptive Content Analysis. Bartın Universitesi Eğitim Fakultesi Dergisi, 7(1), 176-190. [Google Scholar] [CrossRef]

Dyduch, W. (2019a). Entrepreneurial strategy stimulating value creation: Conceptual findings and some empirical tests. Entrepreneurial Business and Economics Review, 7(3), 65-82. [Google Scholar] [CrossRef]

Dyduch, W. (2019b). Organizational design supporting innovativeness. Przegląd Organizacji, (6), 16-23. [Google Scholar] [CrossRef

Dzwigol, H., Aleinikova, O., Umanska, Y., Shmygol, N., \& Pushak, Y. (2019a). An entrepreneurship model for assessing the investment attractiveness of regions. Journal of Entrepreneurship Education, 22(1). [Google Scholar]

Dzwigol, H., Dzwigol-Barosz, M., Miśkiewicz, R., \& Kwilinski, A. (2020). Manager competency assessment model in the conditions of industry 4.0. Entrepreneurship and Sustainability Issues, 7(4), 2630. [Google Scholar] [CrossRef]

Dzwigol, H., Dzwigol-Barosz, M., Zhyvko, Z., Miśkiewicz, R., \& Pushak, H. (2019b). Evaluation of the energy security as a component of national security of the country. Journal of Security \& Sustainability Issues, 8(3). [Google Scholar]

Field, A. P. (2001). Meta-analysis of correlation coefficients: a Monte Carlo comparison of fixed-and random-effects methods. Psychological methods, 6(2), 161. [Google Scholar] [CrossRef]

Fikrat-Wevers, S., van Steensel, R., \& Arends, L. (2021). Effects of Family Literacy Programs on the Emergent Literacy Skills of Children From Low-SES Families: A Meta-Analysis. Review of Educational Research, 1-37. [Google Scholar] [CrossRef]

Fojud, A., Boniecki, P., Zaborowicz, M., Lisiak, D., Ślosarz, P., Stanisz, M., ... \& Konieczny, A. (2017). Project of a computer system supporting extraction of the characteristics of pork half-carcases. Journal of Research and Applications in Agricultural Engineering, 62(3). [Google Scholar]

Glass, G. V. (1976). Primary, secondary, and meta-analysis of research. Educational researcher, 5(10), 3-8. [Google Scholar] [CrossRef] 
Gondek, A., \& Mazur, K. (2014). Metodyka metaanalizy w naukach o zarządzaniu. In W. Czakon (Ed.), Podstawy metodologii badań w naukach o zarzadzaniu (pp. 122-133). Warszawa: Wolters Kluwer Business. [Google Scholar]

Gorynia, M. (2019). Competition and globalisation in economic sciences. Selected aspects. Economics and Business Review, 5(3). [Google Scholar] [CrossRef]

Gorynia, M., Trapczyński, P., \& Bytniewski, S. (2019). The concepts of strategy and business models in firm internationalization research: Towards a research agenda. International Entrepreneurship Review, 5(2), 7-21. [Google Scholar] [CrossRef]

Grudzewski, W. M., \& Hejduk, I. (2006). Wspolczesne kierunki rozwoju nauk o zarzadzaniu. Prace Naukowe Instytutu Organizacji i Zarzadzania Politechniki Wroclawskiej. Studia i Materialy, 79(21), 283-298. [Google Scholar]

Gurevitch, J., Koricheva, J., Nakagawa, S., \& Stewart, G. (2018). Meta-analysis and the science of research synthesis. Nature, 555(7695), 175-182. [Google Scholar] [CrossRef]

Harrington, H. J., \& Voehl, F. (Eds.). (2016). The Innovation Tools Handbook, Volume 1: Organizational and Operational Tools, Methods, and Techniques that Every Innovator Must Know. CRC Press. [Google Scholar]

Heesen, R., Bright, L. K., \& Zucker, A. (2019). Vindicating methodological triangulation. Synthese, 196(8), 3067-3081. [Google Scholar] [CrossRef]

Holmes, B. J., Finegood, D. T., Riley, B. L., \& Best, A. (2012). Systems thinking and dissemination and implementation research. In R.C. Brownson, G. A. Colditz, and E. K. Proctor (Eds.), Dissemination and implementation research in health: Translating science to practice. Oxford: Oxford University Press. [CrossRef]

Hung, C. K. (2019). Knowledge Advancement in Nonprofit and Public Management Research The Potential of Meta-Analysis. Tempe, USA: Arizona State University. [Google Scholar]

Hunter, J. E., \& Schmidt, F. L. (2015). Methods of Meta-analysis: Correcting Error and Bias in Research Findings. 3rd ed. London, UK: Sage Publications. [Google Scholar]

Joslin, R., \& Muller, R. (2016). Identifying interesting project phenomena using philosophical and methodological triangulation. International Journal of Project Management, 34(6), 1043-1056. [Google Scholar] [CrossRef]

Kharazishvili, Y., Kwilinski, A., Grishnova, O., \& Dzwigol, H. (2020). Social Safety of Society for Developing Countries to Meet Sustainable Development Standards: Indicators, Level, Strategic Benchmarks (with Calculations Based on the Case Study of Ukraine). Sustainability, 12(21), 8953. [Google Scholar] [CrossRef]

King, W. R., \& He, J. (2006). A meta-analysis of the technology acceptance model. Information \& management, 43(6), 740-755. [Google Scholar] [CrossRef]

Kostera, M. (2003) Antropologia organizacji. Metodologia badań terenowych. Warszawa: PWN.

Kozmiński, K.A. (2011). Reaktywacja. Warszawa: Poltext.

Kuzior, A., Kwilinski, A., \& Tkachenko, V. (2019). Sustainable development of organizations based on the combinatorial model of artificial intelligence. Entrepreneurship and Sustainability Issues, 7(2), 1353. [Google Scholar] [CrossRef]

Kwilinski, A. (2018a). Mechanism of formation of industrial enterprise development strategy in the information economy. Virtual Economics, 1(1), 7-25. [Google Scholar] [CrossRef]

Kwilinski, A., \& Kuzior, A. (2020). Cognitive Technologies in the Management and Formation of Directions of the Priority Development of Industrial Enterprises. Management Systems in Production Engineering, 28(2), 133-138. [Google Scholar] [ossRefCr]

Kwilinski, A., Drobyazko, S., \& Derevyanko, B. (2019). Synergetic and Value Effects in Corporate Mergers and Acquisitions of International Companies. In Proceedings of the 34th International Business Information Management Association Conference (IBIMA) (pp. 13-14). [Google Scholar]

Kwilinski, A., Vyshnevskyi, O., \& Dzwigol, H. (2020a). Digitalization of the EU Economies and People at Risk of Poverty or Social Exclusion. Journal of Risk and Financial Management, 13(7), 142. [Google Scholar] [CrossRef]

Kwilinski, A., Zaloznova, Y., Trushkina, N., \& Rynkevych, N. (2020b). Organizational and methodological support for Ukrainian coal enterprises marketing activity improvement. In E3S Web of Conferences (Vol. 168, p. 00031). [Google Scholar] [CrossRef]

Kwilinski, A., Shteingauz, D., \& Maslov, V. (2020c). Financial and credit instruments for ensuring effective functioning of the residential real estate market. Financial and credit activity: problems of theory and practice, 3(34), 131-138. [Google Scholar] [CrossRef]

Kyrylov, Y., Hranovska, V., Boiko, V., Kwilinski, A., \& Boiko, L. (2020). International Tourism Development in the Context of Increasing Globalization Risks: On the Example of Ukraine's Integration into the Global Tourism Industry. Journal of Risk and Financial Management, 13(12), 303. [Google Scholar] [CrossRef]

Labarca, C. (2017). Qualitative Research for beginners. Maracaibo, Venezuela: University of Zulia.

Lipsey, M. W., \& Wilson, D. B. (2001). Practical meta-analysis. SAGE publications, Inc. [Google Scholar]

Ludeke-Freund, F., \& Dembek, K. (2017). Sustainable business model research and practice: Emerging field or passing fancy?. Journal of Cleaner Production, 168, 1668-1678. [Google Scholar] [CrossRef]

Lyulyov, O., Pimonenko, T., Kwilinski, A., Dzwigol, H., Dzwigol-Barosz, M., Pavlyk, V., \& Barosz, P. (2021). The Impact of the Government Policy on the Energy Efficient Gap: The Evidence from Ukraine. Energies, 14(2), 373. [Google Scholar] [CrossRef]

Madsen, D. Ø., \& Slatten, K. (2019). Examining the emergence and evolution of Blue Ocean Strategy through the lens of management fashion theory. Social Sciences, 8(1), 28. [Google Scholar] [CrossRef] 
Melnychenko, O. (2019). Application of artificial intelligence in control systems of economic activity. Virtual Economics, 2(3), 30-40. [Google Scholar] [CrossRef]

Melnychenko, O. (2020). Is Artificial Intelligence Ready to Assess an Enterprise's Financial Security?. Journal of Risk and Financial Management, 13(9), 191. [Google Scholar] [CrossRef]

Melnychenko, O. (2021). The Energy of Finance in Refining of Medical Surge Capacity. Energies, 14(1), 210. [Google Scholar] [CrossRef

Merigo, J. M., \& Yang, J. B. (2017). A bibliometric analysis of operations research and management science. Omega, 73, 3748. [Google Scholar] [CrossRef]

Meyer, K., van Witteloostuijn, A., \& Beugelsdijk, S. (2017). What's in ap?: Reassessing best practices for reporting hypothesistesting research. Journal of International Business Studies (JIBS), 48(5), 535-551. [Google Scholar] [CrossRef]

Miśkiewicz, R. (2019). Challenges facing management practice in the light of Industry 4.0: The example of Poland. Virtual Economics, 2(2), 37-47. [Google Scholar] [CrossRef]

Miskiewicz, R. (2020a). Internet of Things in Marketing: Bibliometric Analysis. Marketing and Management of Innovations, 3, 371-381. [Google Scholar] [CrossRef]

Miśkiewicz, R. (2020b). Efficiency of Electricity Production Technology from Post-Process Gas Heat: Ecological, Economic and Social Benefits. Energies, 13(22), 6106. [CrossRef] [CrossRef]

Miśkiewicz, R., \& Wolniak, R. (2020). Practical Application of the Industry 4.0 Concept in a Steel Company. Sustainability, 12(14), 5776. [Google Scholar] [CrossRef]

Mohajan, H. K. (2018). Qualitative research methodology in social sciences and related subjects. Journal of Economic Development, Environment and People, 7(1), 23-48. [Google Scholar]

Oesterreich, T. D., Schuir, J., \& Teuteberg, F. (2020). The Emperor's New Clothes or an Enduring IT Fashion? Analyzing the Lifecycle of Industry 4.0 through the Lens of Management Fashion Theory. Sustainability, 12(21), 8828. [Google Scholar] [CrossRef] Patton, M. Q. (2002). Qualitative research and evaluation methods. Thousand Oaks. Cal.: Sage Publications, 4.

Pyrczak, F. (2016). Writing empirical research reports: A basic guide for students of the social and behavioral sciences. London, UK: Routledge. [Google Scholar]

Quinlan, Ch., Babin, B., Carr, J., \& Griffin, M. (2019). Business Research Methods. 2nd Edition. Mason. OH: South Western Cengage Learning. [Google Scholar]

Rahi, S. (2017). Research design and methods: A systematic review of research paradigms, sampling issues and instruments development. International Journal of Economics \& Management Sciences, 6(2), 1-5. [Google Scholar]

Sacks, H. S., Berrier, J., Reitman, D., Ancona-Berk, V. A., \& Chalmers, T. C. (1987). Meta-analyses of randomized controlled trials. New England Journal of Medicine, 316(8), 450-455. [Google Scholar] [CrossRef]

Sagan, A. (2009). Metaanaliza danych w marketingu zorientowanym na dowody - orientacja kliniczna w badaniach rynkowych i marketingowych. Prace Naukowe Uniwersytetu Ekonomicznego we Wroclawiu, 51. 114-124. [Google Scholar]

Sauerbrei, W., \& Blettner, M. (2003). Issues of traditional reviews and meta-analyses of observational studies in medical research. Meta-analysis: new development and applications in medical and social science. Munchen: Hogrefe \& Huber.

Saunders, B., Sim, J., Kingstone, T., Baker, S., Waterfield, J., Bartlam, B., ... \& Jinks, C. (2018). Saturation in qualitative research: exploring its conceptualization and operationalization. Quality \& quantity, 52(4), 1893-1907. [Google Scholar] [CrossRef]

Schwartz-Shea, P., \& Yanow, D. (2013). Interpretive research design: Concepts and processes. Routledge. [Google Scholar]

Thompson, S. G., \& Sharp, S. J. (1999). Explaining heterogeneity in meta-analysis: a comparison of methods. Statistics in medicine, 18(20), 2693-2708. [Google Scholar] [CrossRef]

Tkachenko, V., Kwilinski, A., Kaminska, B., Tkachenko, I., \& Puzyrova, P. (2019a). Development and effectiveness of financial potential management of enterprises in modern conditions. Financial and credit activity: problems of theory and practice, 3(30), 8594. [Google Scholar] [CrossRef]

Tkachenko, V., Kwilinski, A., Klymchuk, M., \& Tkachenko, I. (2019b). The Economic-Mathematical Development of Buildings Construction Model Optimization on the Basis of Digital Economy. Management Systems in Production Engineering, 2, 119-123. [Google Scholar] [CrossRef]

Trajer, J., Paszek, A., \& Iwan, S. (2012). Zarządzanie wiedzą. Warszawa: PWE.

Vaivio, J., \& Sirén, A. (2010). Insights into method triangulation and "paradigms" in interpretive management accounting research. Management Accounting Research, 21(2), 130-141. [Google Scholar] [CrossRef]

Vazquez, F. L., Otero, P., García-Casal, J. A., Blanco, V., Torres, A. J., \& Arrojo, M. (2018). Efficacy of video game-based interventions for active aging. A systematic literature review and meta-analysis. PloS one, 13(12), e0208192. [Google Scholar] [CrossRef]

Williams, A., Kennedy, S., Philipp, F., \& Whiteman, G. (2017). Systems thinking: A review of sustainability management research. Journal of Cleaner Production, 148, 866-881. [Google Scholar] [CrossRef]

Kwilinski, A. (2018b). Mechanism of Modernization of Industrial Sphere of Industrial Enterprise in Accordance with Requirements of the Information Economy. Marketing and Management of Innovations, 4, 116-128. [Google Scholar] [CrossRef] 
Генрік Двізол, D.Sc., професор, Сілезійський технологічний університет, Польща

Мета-аналіз як інструмент підвищення якості наукових досліджень: на прикладі галузі менеджменту

Систематизація наукових напрацювань, присвячених питанням методологічного інструментарію наукових досліджень, свідчить про недостатній рівень опрацювання питань емпіричного підходу до забезпечення якості дослідницького процесу. У рамках даної статті проаналізовано детермінанти якості дослідницького процесу в менеджментології. Емпіричне дослідження проведено з використанням інструментарію аналізу головних компонент (факторного аналізу). У статті автором представилено цілісну, упорядковану та налаштовану структуру для побудови методології дослідження. Автором наголошено, що дослідження у галузі менеджментології мають включати практичну та теоретичну частини. Так, попри прикладний або практичний характер менеджментології, особливу увагу необхідно приділяти теоретичним дослідженням. Головною метою роботи є визначення детермінант, як додаткових елементів сучасних методологічних підходів, що впливають на дослідницький процес. Систематизація наукових напрацювань свідчить про трансформації у методах управління. Так, методологія управління постійно доповнюється новими методами, які мають різні рівні пізнавальної та практичної ефективності. Автором зазначено, що головним поштовхом у розвитку діагностичних інструментів стали зміни у навколишньому середовищі та необхідність використання більш складних та ефективних інструментів. У рамках роботи, автором висвітлено особливості проведення мета-аналізу та застосування якісного підходу до проведення наукових досліджень. За результатами емпіричного дослідження доведено наявність детермінант, за якими можливо здійснити оцінювання якості наукового дослідження. Автором доведено, що якість дослідницького процесу у менеджментології визначається за допомогою перевірки узгодженості цілей дослідження відповідно до його проблематики та висновків.

Ключові слова: мета-аналіз, менеджмент, дослідження, детермінанти, якість, емпіричний підхід. 